https://doi.org/10.18485/slav_markovic_slobodan.2018.ch11

УДК 821.163.41.09 Црњански, Милош

СЕРГЕЙ Н. МЕЩЕРЯКОВ*

МГУ им. М.В. Ломоносова

Филологический факультет

Кафедра славянской филологии

\title{
МИЛОШ ЦРНЯНСКИЙ: ОПЫТ СТОЛЕТИЙ И ЦИВИЛИЗАЦИЙ
}

\footnotetext{
В статье выявляется взаимодействие в произведениях сербского писателя М. Црнянского опыта экспрессионизма, романтизма и барокко с традициями буддизма. Творчество Црнянского стало воплощением единства достижений европейской и восточной цивилизаций.

Ключевые слова: Црнянский, экспрессионизм, романтизм, барокко, буддизм
}

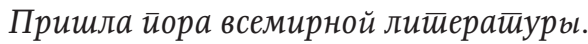
Гете - Эккерману (31 января 1827 г.)

Крупнейший представитель сербского экспрессионизма, М. Црнянский начал свой творческий путь с разрыва с традицией, что представлялось вполне закономерным. «Авангард игнорировал традицию и радикально порвал с нею. Отрицая предшествующее искусство и литературу, он был устремлен к абсолютному началу в творчестве и совершил решительную переоценку всех ценностей, вначале только эстетических, а затем и этических, идеологических и политических», - отмечал Р. Д. Клуге (1985: 89). В «Лирике Итаки» Црнянский стремится разрушить устоявшиеся стереотипы, мифы о национальном величии, созданные в том числе и литературой романтизма.

О Балще, и Душане Сильном, иуусйь умолкней крик.

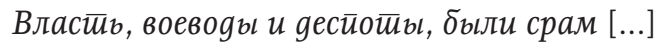

Писал он в стихотворении «Памяти Принципа». По словам поэта, «Марко» «тошнит от пробуждения», а Грачаницы «больше нет» («Наша элегия»). И потому чуть далее утверждается:

·pionerskaya@bk.ru 
Да буяуй йроклятй йобеgа и воодушевление.

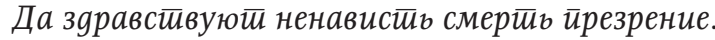

Однако демонстративный разрыв с мифами, созданными романтизмом, не означал отказа писателя от достижений этого направления. Родство сербского авангардизма с романтизмом было очевидно и отмечалось многими критиками: В. Глигоричем, М. Богдановичем, И. Секулич. При этом, по словам И. Секулич, именно Црнянский представлял тип «чистейшего романтика» (Црњански 1972: 36). Сам М. Црнянский полагал, что романтизм - лучшая эпоха сербской литературы и говорил о его важности для современности. Он защищал «неистового романтика» Л. Костича. Им было написано несколько статей о Негоше и Змае. Црнянский даже ожидал обвинений в том, что его «суматраизм» - это «лишь подогретый романтизм». ${ }^{1}$

Уже первое произведение писателя драма «Маска» была написана, по его словам, «из перспективы романтизма» $(4,187)$ : там были и любовь, и донжуанская страсть, и несчастный случай, и самоубийство. Одним из героев «Маски» был поэт-романтик Бранко Радичевич.

Однако романтизм Црнянского несколько отличался от романтизма традиционного. «Маска» была названа «комедией», в роли ДонЖуана выступала женщина (Генеральша), ее любовником оказывался ее племянник, а точнее, незаконнорожденный сын (Чезаре). И наконец, сама ситуация с маской, приведшая к путанице, любовной встрече сына с матерью и его самоубийству, свидетельствовала о призрачном, обманчивом характере этого мира, «ставшего, на взгляд экспрессионистов, всего лишь собственной маской» (Топоров 1990: 13). В «романтизме» Црнянского проявлялись и современные тенденции, влияние фрейдизма.

В дальнейшем творчестве писателя, в частности во «Второй книге Переселений», романтизм проявляется с особой силой: главное действующее лицо романа, сербский офицер Павле Исакович, действующий в середине XVIII в., показан как типичный романтический герой. Он исключительно красив, в его жизни существуют «два идола»: возлюбленная и отечество. Возлюбленная, в соответствии с романтической традицией, умирает, но Исакович никогда не забывает о ней. Подобно романтическому герою, Павле присущи приступы безумия. Причем «безумный смех» и «безумный взгляд» Исаковича воспринимаются окружающими не как признаки болезни, а как особые, специфические моменты в поведении героя.

${ }^{1}$ Црњански М. Сабрана gела. Београд, 1966.Т. 6. С. 19. Здесь и далее цитируется по данному изданию, том и страница указываются в тексте статьи. 
При этом, конечно, Црнянский, писатель XX в., вносит определенные коррективы в традиционный романтический образ героя. Так, умершая возлюбленная героя - его бывшая жена, которую он не любил при жизни. Исакович наивен: его противники разыгрывают перед ним спектакль и убеждают его, что жена одного из офицеров - это императрица Елизавета Петровна. Иногда Павле напоминает Ансельма из «Золотого горшка» Гофмана.

С романтизмом связано обращение писателя к фольклору. М. Матицкий в статье об эпосе воеводинских сербов в «Переселениях» Милоша Црнянского отметил общность мотивов в романе и народной песне, подчеркнул сходство изображения фактов и указал на идентичность композиции романа и хроники военного похода (Црњански 1972: 199).

С другой стороны, и при изображении мирной жизни Црнянский, по словам Матицкого, сохранил близость фольклору. Это и народные легенды, например, о мертвом солдате, вернувшемся с войны, и верования в вампиров, и народные обычаи. Обращение к фольклору свидетельствовало как о верности исторической картины, так и о лирическом начале, присущем роману Црнянского.

Интерес писателя к романтизму не ограничивался национальной традицией: его привлекает творчество Флобера, «романтика в лучшем смысле этого слова», романтика, полюбившего «античный мир как грандиозную картину могущества человека» $(10,163,165)$. «Саламбо» для Црнянского, как и для Флобера, не был историческим романом, хотя французский писатель опирался на прекрасное знание истории. Флобер «видел в истории не прошлое, а вечность» $(10,167)$.

Точно так же и Црнянский в «Переселениях» на примере конкретных событий середины ХУШ в. раскрывает идеи «утопического космизма», которые воспринимаются критикой и как проявление мистически ориентированного символизма ${ }^{2}$. Юг и Север, Суматра и Гиперборея «важнейшие символы, за которыми скрываются целые миры» $(10,116)$. Символичны Итака и Сербия, Стражилово и Шпицберген, Фрушка Гора и Урал. Однако главный символ Црнянского - Небо. Первая и последняя глава «Переселений» названы одинаково: «Бескрайний голубой круг. И в нем, звезда». При этом известно, что «круг с точкой посередине представляет завершенный цикл и циклическое совершенство, разрешение всех экзистенциальных возможностей; в астрологии он обозначает Сол-

${ }^{2}$ По словам П.Палавестры, писатель « в глубине души не отказался от наследия мистически ориентированного символизма и устремленности романтиков к самопознанию и исповеди» Итиака. Ревија за књижевност, уметност и мишлење. Нулти број. Београд. 1995. С. 68. 
нце ... а также символизирует всех богов солнца» (Купер 1986: 79-80). Культ Солнца у Црнянского вновь находит свое воплощение.

Ощущение вечности, присущее Црнянскому, влечет писателя к Кьеркегору, Ибсену, Стриндбергу, в чем он сам неоднократно признается. По его мнению, они обращаются к важнейшим философским вопросам и пишут для всего человечества: «... Главные темы этих писателей - вечные, античные. Отец. Мать. Мужчина и женщина. Эдип. Иокаста. Семья. Любовь и неумолимая наша судьба ... Я нахожу в этой литературе серьезность, которой в Париже больше нет ... Кьеркегор, Ибсен, Стриндберг ... говорят ... о том, что всех нас привлекает: инстинкт эроса, инстинкт смерти. А и по социальным вопросам они бы не провались на экзамене $(8,46-47)$.

Выбор Црнянским Кьеркегора, Ибсена и Стриндберга, очевидно, был закономерен. Творчество Ибсена, по словам сербского писателя,«параллель человеческой жизни. Сон. Пер Гюнт - это сон. И не только Ибсена. И норвежского фольклора. Всего народа» $(8,49)$. Стриндберг, в свою очередь, испытал влияние Ницше и стал одним из предшественников экспрессионизма. К творчеству Ибсена и Стриндберга впоследствии обращался М. Крлежа, крупнейший хорватский писатель-экспрессионист того времени.

Сам Црнянский, говоря об Эдипе, Иокасте и неумолимой судьбе, прокладывал дорогу через труды Фрейда к античной трагедии. По его словам, писатели-скандинавы вернули его к философским размышлениям о человеческой жизни. «До сих пор я иронизировал над Эдиповым комплексом, Фрейд был мне смешон, - писал Црнянский. - Теперь уже нет» $(8,48)$. Далее, указывая на значимость обращения к психоанализу, Црнянский писал: «Росмерсхольм» Ибсена представлялся мне занимательной, отличной драмой, театром. Но никак не великим произведением. Когда я прочитал, что Фрейд говорит о «Росмерсхольме», Ибсен мне показался чем-то наподобие Еврипида своего времени. А это много значит» $(8,68)$. По словам сербского писателя, «судьба была драматическим элементом в творчестве Ибсена, а также всей его жизни» $(8,69)$.

Обращение к античности («Лирика Итаки») - это обращение к трагедии ${ }^{3}$. Это обращение к судьбе, которая может быть чрезвычайно жестока и иронична по отношению к человеку. Так, сам Црнянский переживает судьбу Одиссея, проведя в изгнании в Англии двадцать лет (1945-1965), Владислав Петкович-Дис, автор сборника стихов «Утонувшие души», тонет в Ионическом море.

С другой стороны, мысль о всевластии Судьбы унижает человека, что закономерно рождает в нем чувство протеста и ведет его к осозна-

\footnotetext{
${ }^{3}$ Интерес к античности лежит в основе «Рождения трагедии» Ф. Ницше.
} 
нию собственной свободы, готовности понести наказание за свои действия. «Античная драма связана с пробуждением в человеке чувства личности и личной ответственности» (Костелянец 2007: 36). Судьба Чезаре («Маска») напоминает об Эдипе.

Своеобразным мостом между скандинавскими писателями и античностью предстает у Црнянского Микеланджело, которым также интересовались экспрессионисты. «...Во время моего путешествия к вечным льдам Гипербореи, - отмечал М. Црнянский, - я читал на корабле этих северных писателей, хотя сейчас все чаще читаю Микеланджело» (8, 46). По его словам, Микеланджело, воздействуя на Ибсена, воздействовал на всю европейскую литературу. «Все до своего приезда в Рим Ибсен не представлял ничего особенного. Под влиянием купола Микеланджело... Ибсен чрезвычайно изменился. А затем он изменил не только свою национальную литературу, но и свой театр, а после, можно сказать, и всю Европу» $(8,63)$. Ибсен после Микеланджело, по словам Црнянского, отказывается от христианского Бога, который якобы состарился, и «ищет нового бога, молодого, как и Микеланджело, какого-то Юпитера, с молниями, на Олимпе, какого желал и сам художник» $(8,64)$.

От «состарившегося» христианского Бога один шаг к признанию Его смерти, а от уподобления человека языческому божеству - один шаг к «сверхчеловеку». «Сверхчеловеку», обладающему всей полнотой власти, способному повести за собой массы. Таким «вождем», «гением» и «сновидцем» предстает Микеланджело и в пьесе-«легенде» М. Крлежи «Микеланджело Буонаротти» (1917). Впрочем, у экспрессионистов были общепризнанные «пророки»: Христос, Дарвин, Маркс, Ницше и Фрейд - те, кто, по мнению «молодых», могли повести за собой человечество ${ }^{4}$. При этом некоторые экспрессионисты, например Иоганнес Бехер, пытались примирить социализм с христианством.

«Социалист» Црнянский также проявлял некоторый интерес к христианству, читал Фому Аквинского, но все же остался «язычником». Для него Бог - «бесконечность во Вселенной» $(7,403)$, жизнь на Земле вечно продолжается, переселяясь из одного облика в другой, никакого «иного света» не существует. «Достоинство человека заключено в верности Земле - в этом Црнянский идет по пути Ницше», - пишет Д. Стоянович (1985: 48). При этом европейские корни вечности бытия и «переселения» следует искать в античности, у Платона, на которого, как считается, повлияли индийские религиозные представления. Впоследствии эта идея находит несколько иное воплощение в раннем средневековье («Первоосновы теологии» Прокла), чтобы в новое время прозвучать у Метерлинка.

\footnotetext{
${ }^{4}$ Энциклопедия экспрессионизма. М., 2003. С. 184.
} 
Как отмечал Е. Г. Яковлев, «Метерлинк в философском эссе «Смерть» развивает идеи, очень близкие идеалистическим аспектам буддийского миросозерцания. Он пишет о том, что абсолютное уничтожение человека и сознания невозможно и что величайшая цель саморазвивающегося бытия заключается в уничтожении страдания» (Яковлев 1985: 143). Несколько ранее к буддизму обращаются Шопенгауэр и Ницше, и благодаря их усилиям это учение начинает распространяться на Западе. Так, В. Воррингер, автор работы «Абстракция и вчувствование» (1908) и, как полагают, автор самого термина «экспрессионизм», отмечал, что искусство должно обратиться к Востоку с его изначальным мистицизмом и космической религиозностью. ${ }^{5}$

О рецепции восточных духовных ценностей сербами пишет Р. Вучкович (2003: 184). Так, накануне первой мировой войны П. Слепчевич опубликовал статьи «Нирвана» и «Парсифаль», а в 1917 году он защитил докторскую диссертацию «Буддизм в немецкой литературе». В дальнейшем, после войны, увлечение сербских экспрессионистов «индийско-китайской мудростью и поэзией» стало, по словам Вучковича, «всеобщим».

«Всеобщим» оно, стало, вероятно, после Црнянского, издавшего в 1923 году «Антологию китайской лирики», а в 1928 году «Поэзию древней Японии». Признав, что китайский и японский лиризм в Сербии «совершенно неизвестен», писатель отметил его значимость для «молодых», открывающих «новые горизонты для нашей литературы». Восток, по словам Црнянского, - это воплощение «небесной мудрости» и всего «прозрачного, мирного, вечного». Что же касается Европы, то ее, к сожалению, коснулась «лишь слабая тень буддизма» (4, 281-282).

Впрочем, начинает Црнянский не с буддизма, а с даосизма, с Лао-цзы. В целом переводы Црнянского достаточно точны: хотя он переводил с английского и французского языков, но консультировался при этом у китайских и японских студентов. Вместе с тем в сравнении с современным профессиональным переводом у Црнянского наблюдаются некоторые погрешности. Так, «Книга пути и благодати» Лао-цзы переводится Црнянским как «Книга о смысле и добродетели» («Книга о смислу и врлини»), а Дао (в современной сербской транскрипции также «Дао») транскрибируется как «Тао».

Вслед за даосизмом у Црнянского идет Конфуций, представленный, впрочем, в несколько необычном аспекте. В первом стихотворе-

\footnotetext{
${ }^{5}$ В ходе дискуссии о культурах Востока и Запада, развернувшейся в Китае в 1920е гг., Ли Да-чжао в работе «Особенности основ цивилизации Востока и Запада» утверждал необходимость формирования мировой культуры на основе их синтеза. См.: Артамонов С. Д. История зарубежной литературы XVII-XVIII веков. М., 1988. С. 11.
} 
нии китайский мудрец утверждает важность лирического начала, а во втором пишет о преходящем характере жизни и вечном круговороте в природе. Размышления о теории и практике управления, вероятно, не укладывались в стихи.

Наконец, близость к буддийскому миросозерцанию проявляется в стихах неизвестного автора, записанных на надгробном памятнике в горах Фу-Киу, где умершая просит, чтобы «в бесконечном круге перерождений» ее тело «не появилось бы вновь на земле».

Отголоски конфуцианства в творчестве Црнянского практически не заметны. О даосизме напоминает интерес к Небу («Небо следует (законам) Дао» - «Дао дэ Цзин»), а также раздвоение личности героя «Переселений» Вука Исаковича. Герой ведет свой полк на погибель во имя чуждых интересов, и его переживания напоминают внутренний конфликт даоса. «...Служить неправому делу и мириться с дурными порядками даосу не позволяли ни истинное конфуцианство, ни тем более даосизм. В противном случае он вступал в конфликт с самим собой, что могло вызвать раздвоение личности» (Абаев 1983: 73).

Более очевидными и несомненными представляются параллели Црнянского с буддизмом ${ }^{6}$. Устремленность к Небу присуща чань-буддизму. «Будда - лазурный небосвод», - утверждает школа юньмэнь. Но главное, что «суматраизм», то есть любовь и единение личности с окружающим миром, полностью совпадает с «безграничной буддийской любовью» и «слиянием человека с природой» $(4,334)$. «Мысль о нерасчлененности субъекта и объекта, человека и природы»- «фундаментальная идея буддийской гносеологии» (Яковлев 1985: 146). При этом единство субъекта и объекта проявляется у Црнянского не только в лирике («Смерть моя зависит от пения птиц» - стихотворение «Ветры»), но и во «Второй книге Переселений», где главный герой Павле Исакович во время скачек ощущает внутреннее единство со своей кобылой Лисой. Вследствие этого она сама идет на чрезвычайно опасные препятствия и берет их. Одна из наиболее прочувствованных, романтических сцен в произведении в то же время предстает как воплощение буддийского миросозерцания.

В духе буддизма Црнянский в конце «Второй книги Переселений» утверждает призрачность единичного явления. По словам писателя, одинокий человек - это ничтожная песчинка, выброшенная на берег после шторма, его смерть остается в людской памяти не дольше мгно-

\footnotetext{
${ }^{6}$ Речь далее в основном пойдет о махаяне и ее школе мадхъямака, а также о чань и дзэн-буддизме. При этом не следует забывать, что чань-буддизм во многом наследовал традиции даосизма.
} 
вения - взмаха крыльев ночного светлячка. Всем народам известно, что одиночка - всего лишь жалкая частица праха.

Роднит Црнянского с буддизмом и метод интуитивного познания мира, который очевидно проявляется в «Объяснении «Суматра»». То, что происходит с героем «Объяснения ...», иначе как «озарением» или «просветлением», лежащем в основе чань-буддизма, назвать нельзя. Однако в данном случае нельзя отрицать и влияния Бергсона. « ... Црнянскому, как и экспрессионизму в целом, Бергсон, так сказать, открыл двери интуитивного познания, без чего суматраизм невозможно представить», - отмечал М. Лончар (Црњански 1972: 97).

«... По буддийскому учению, все переживаемое в эмпирическом мире - иллюзия ...»- писал О. О. Розенберг ${ }^{7}$, и в соответствии с важнейшим постулатом йогочары-мадхъямаки (то есть «высшей школы срединности») сансара - это не окружающий мир, а просто сон- следствие заблуждений человека. В то же время для Црнянского мотив сна крайне важен. Так, главный герой «Переселений» Вук Исакович в начале романа пробуждается ото сна, а в конце погружается в сон. Да и в целом весь мир превращается для героя в подобие сна. «Разъезжая за полком, словно огромный мех, полный вина, Вук Исакович видел из своей повозки мир, словно какой-то сон» $(1,206)$. Мотив сна повторяется в «ПереселенияХ» десятки раз.

В какой-то мере сближает Црнянского с буддизмом и обращение к роману - параболе («Переселения», «Вторая книга Переселений», «Роман о Лондоне»), так как для буддизма характерно тяготение к притче, образной метафоре и сравнению. Впрочем, обращение к притче характерно и для Евангелия, и Црнянский, безусловно, ранее познакомился с притчами Христа, чем Будды.

То, что очевидно свидетельствует об интересе Црнянского к буддизму, заложено в символическом названии романа «Переселения», хотя применительно к буддизму в целом точнее говорить о «перерождении». В конце «Второй книги Переселений» приводится печальная статистика полного вымирания сербского «национа» в России. И тут же в качестве неожиданного итога звучат слова: «Есть переселения. Смерти нет!», что перекликается с упомянутым эссе Метерлинка «Смерть», равно как и с брахманизмом и учением Платона.

Можно предположить, что Црнянский здесь опирается на известный принцип противоречия: категорическое утверждение закономерно порождает утверждение противоположное, печальные факты рождают надежду и даже уверенность в лучшем будущем. Однако яснее всего это противоречие раскрывается сквозь призму дзэн-буддизма. В концепции

\footnotetext{
${ }^{7}$ Розенберг О. О. Труды по буддизму. М.,1991. С. 184.
} 
«саби» («патины времени») звучит жизнеутверждающая мысль о возвращении всего живого к своему началу, «ржавчине веков», что предполагает новое рождение, вечность. Крупнейший в мире исследователь буддизма Дайсэцу Тайтаро Судзуки писал в труде «Основы дзэн-буддизма»: «Нет рождения и смерти: нет начала и конца - вот что такое восточный образ мышления!»

О близости буддизму свидетельствует понятие «пустоты», которое постоянно, более двадцати раз, встречается в «Переселениях». При этом речь идет как о «пустоте» жизни, то есть ее бессмысленности и тщетности, так и о «пустоте» конкретного пространства и о пустоте Вселенной. ${ }^{9}$

Размышления о пустоте жизни наиболее многочисленны и часто звучат как рефрен (недаром и Црнянский и критики называли «Переселения» «поэтическим» романом). Так, в середине восьмой главы Црнянский, размышляя о судьбе Вука Исаковича, начинает абзац словами: «Пусто все, значит, было перед ним», а следующий абзац продолжает мысль предыдущего: «Перед пустотой пропасти, разверзшейся бездны, на краю которой он оказался... $(1,273)$. И этими же словами начинаются два идущих друг за другом абзаца в конце заключительной, десятой главы, что возвращает мысль к предшествующей ситуации и усиливает воздействие на читателя.

С другой стороны, «пустота» обретает у Црнянского близость физическому явлению. Так, Вук Исаакович выезжает из лагеря « в пустое, звездное утро», он видит трех повешенных «над пустынными, далекими полями», « в пустоте за ними кружились стаи воробьев», а хижина Вука Исаковича тонет во «Тьму и безмерную пустоту» $(1,262,277,278,176)$.

Размышление о «пустоте» Вселенной в романе единично и психологически мотивированно. Вук Исакович, наговоривший австрийскому епископу много опасных слов о «сладком православии», пытается стереть их смысл у собеседника рассуждениями о бессмысленности жизни, которые представляются все же не столь опасными, как слова о преданности православию, то есть России. «Души нет ... как и Бога нет... тщета одна... тлен... смерть... пустые слова ... а не значит ли, что все это лишь бездонная пустота?» $(1,157)$

Трудно представить, чтобы необразованный сербский майор в XVIII веке из-за неудовлетворенности своим положением (он никак не может получить чин подполковника) и положением своего полка приходит к отрицанию Бога и души. Но если за «признанием» героя стоит ав-

\footnotetext{
${ }^{8}$ Буддизм. Четыре благородные истины. Москва-Харьков, 1999. С. 372.

${ }_{9}^{9}$ Утверждение Црнянского о пустоте Вселенной могло опираться также на достижения астрономии его времени. См.: Радуловић М. Модернизам и српска идеалистичка философија. Београд, 1989. С. 172.
} 
тор, то параллели с буддизмом представляются несомненными. «Представление о том, что мир непременно должен быть кем-нибудь создан, - это как раз та мысль, опровержению которой буддийские философы посвятили особенно много сил; что же касается бессмертия души, то буддисты отрицают не только существование ее после смерти тела, но и правомерность самого этого понятия» (Шабуров 1997: 50).

Кажется, что «пустота» для Црнянского - явление отрицательное, негативное, враждебное человеку и свидетельствует лишь о тщетности и «ничтожности» жизни. По словам С. Корача, появление «пустоты» объясняется отсутствием Бога: «Если Бога нет, весь мир - пустота. И горы, и поля, и крыши домов, и лунный свет, и светящееся небо. Все это не может понять Вук Исакович, и все же он должен примириться с тем, что мир остался пуст без Бога. Это чрезвычайно важное философское положение романа «Переселения» (Кораћ 1982: 191).

Подобная трактовка философских воззрений Црнянского может быть допустима. Однако представление о мире как «пустоте» гораздо лучше согласуется с буддийским учением, признающим пустоту в качестве всепорождающей основы. Так, в «учении о пустоте» Нагарджуна, исходя из закона зависимого возникновения, доказывал, что всякое существование чем-то обусловлено, а потому ничто не обладает подлинной реальностью и окружающий человека мир пуст.

При этом, если следовать логике С. Корача, трудно примирить по-христиански понимаемую «пустоту», «ничтожество», «небытие» следствие отсутствия Бога - с любовью и мистическим «всеединством» суматраизма Црняского. Однако с точки зрения буддизма такое совмещение «пустоты» и «всеединства» закономерно. У каждого отдельного явления есть причина, и следовательно, оно не обладает истинным, независимым существованием. «Но когда речь заходит обо всех явлениях вместе, о мироздании в целом, то мы как бы рисуем окружность, внутри которой оказываются и все следствия, и все причины. И тогда пустой мир внезапно наполняется. Явления, каждое из которых в отдельности нереально, все вместе составляют единственно реальное, единственно подлинное - мир в целом» ${ }^{10}$.

Буддийское понимание «пустоты» как основы мироздания, его единства в полной мере присущи Црнянскому. Так, в начале и в конце произведения Вук Исакович гонит коня «сквозь пустоту» $(1,131,355)$. При этом значительный текст (более страницы), повторяется, как рефрен, почти дословно, хотя в первом случае Исакович «шел на войну» и «ветер дул ему в лицо», а во втором Вук Исакович «возвращался с войны» и «ветер дул ему в спину». Очевидна символическая значимость

${ }^{10}$ Шабуров Н.В и др. Религии мира. С. 79. 
этих отрывков, сводящих начала и концы романа, и тем большее внимание привлекает понятие «пустоты» в данном случае. Сразу возникают ассоциации с «Суматрой» (герой смотрит на «далекие холмы»), появляется «Солнце», которому Црнянский, по его же словам, поклонялся ${ }^{11}$. Вук Исакович, «просиявший» в солнечном свете, ощущает необыкновенную легкость, как будто он и не едет верхом на коне, как будто он и «не существует». Очевидно, что здесь речь идее о «пробуждении», когда человек чувствует слияние с Пустотой и ощущает единство со всей Вселенной, а его «эго» как бы растворяется в мире.

Парадоксальность, противоречивость буддизма («пустота», призрачность мира и вместе с тем его реальность и подлинность, противопоставление сансары нирване и стирание их отличий, тенденции к дуализму и нейтрализации оппозиций, обращение к интеллекту и в то же время к интуиции, отрицающей его) совпадает с аналогичным видением жизни Црнянским. У сербского писателя также возникает высокое напряжение между полюсами, проявляется стремление соединить, казалось бы, несоединимое. Так, экспрессионизм - воплощение субъективного начала ${ }^{12}$ - у Црнянского сочетается с буддизмом, отрицающим индивидуальность и «душу». Признание традиции не отменяет разрыва с ней. В «Комментариях» к «Лирике Итаки» писатель почти сразу дает главу «Биографические сведения о поэте», полностью посвященную его предкам и родственникам, и в то же время в последнем абзаце этой главы заявляет: «Что же касается меня, то, в отличие от принятого у нас образа мыслей, я никогда не интересовался ни тем прошлым, ни собственным происхождением. Я всегда был сам себе предок» $(4,111)$. Противоречивость суждений писателя отмечает Г. Я. Ильина, анализируя роман «Записки о Чарноевиче» ${ }^{13}$.

Соединение у Црнянского противоположностей напоминает не только о буддизме, но и о барокко с его антиномиями. Тем более, что интерес к барокко проявляется в Европе почти одновременно с интересом к буддизму. Отметим статью Х. Ортеги - и Гассета «Воля к барокко», появившуюся в 1915 году, где утверждается близость барокко современной эпохе: «Как бы то ни было, интерес к барокко растет с каждым днем. Теперь Буркхардту не понадобилось бы в «Cicerone» просить прощения

${ }^{11}$ Появление Солнца, солнечного света может быть истолковано в данной ситуации в духе буддизма, точнее, его подшколы йогачара - мадхъямака. В рамках ее учения ум по сути своей - пустота, а по природе - светоносная ясность. Следовательно, ясность и пустота оказываются неразделимы, что было представлено у Будды как «Ясный Свет».

12 «Экспрессионизм осмыслил себя как предел возможной субъективности» //Энциклопедия Экспрессионизма. С. 391.

${ }^{13}$ Ильина Г. Я. Развитие югославского романа в 20-30-е годы ХХ в. М., 1985. С. 41. 
у читателей за свои занятия творениями семнадцатого века. И хоть нет у нас еще четкого анализа основ барокко, что-то притягивает нас к барочному стилю, дает удовлетворение» ${ }^{14}$ В этом же году В.Штамлер говорит о «литературе барокко», в дальнейшем, в начале 20-х гг., А. Хюбшер представляет барокко как оформление антитетического жизненного чувства.

Антиномии, присущие барокко, выявляются у Црнянского в полной мере. И у сербского писателя и в барокко интеллектуальный подход к действительности сочетался с проявлением интуиции. «Философские горизонты творчества Милоша Црнянского» ${ }^{15}$ озарялись молниями прозрений, запечатленными в «Объяснении «Суматры», а в барокко интеллектуальное напряжение дополнялось «вкусом», способностью ума к интуитивной деятельности. «Поэтический стиль барокко складывался из двух противоборствующих элементов - фантазии и разума», - писал А. Л. Штейн ${ }^{16}$.

В духе барокко у Црнянского представлено соединение многочисленных философских рассуждений и любовно- авантюрного сюжета, являющегося одним из элементов традиционного исторического романа. На своем пути в Россию Павле Исакович встречает множество препятствий: его арестовывают, ему грозит военно-полевой суд, он бежит из-под ареста, с огромным риском для жизни добирается до Вены, попадает в русское посольство, получает российский паспорт, выполняет довольно опасное задание русского дипломата. При этом Евдокия Божич и ее дочь пытаются соблазнить героя и отвратить его от избранного пути, а сам Божич впоследствии организует покушение на Павле. В дальнейшем на пути в Россию герой встречается со своим соотечественником Вишневским, видным русским чиновником, который также изо всех сил препятствует осуществлению замысла Павла. Авантюрный сюжет в произведении Црнянского напоминает о барочном романе испытания.

Барокко присущи устремленность к Небу и в то же время демонизм ${ }^{17}$. То же и у Црнянского: не случайно М. Ломпар проводит параллель между писателем и Мефистофелем ${ }^{18}$. Действительно, если Бог всего лишь «бесконечность во Вселенной» или подобие Юпитера, то

\footnotetext{
${ }^{14}$ Ортега-и-Гассет Х. Эстетика. Философия культуры. М., 1991. С. 152

${ }^{15}$ Милошевић Н. Филозофска димензија књижевних дела Милоша Црњанског // Црњански. М. Сабрана дела. 1 С. 9-116.

${ }^{16}$ Штейн А. Л. Литература испанского барокко. М., 1983. С. 17. Отметим, что слова Штейна о «поэтическом стиле барокко» напоминают о «поэтическом стиле» Црнянского.

17 А. Л. Штейн отмечал, что в пьесе Аларкона «Ткач из Сеговии» «есть особый оттенок, привнесенный барокко. Герой заключает в себе нечто демоническое и нечеловеческое» //Литература испанского барокко. М., 1983. С. 59.

18 Ломпар М. Црњански и Мефистофел. Београд, 2000.
} 
христианским понятиям здесь нет места. Точно так же барокко, признавая бесконечность пространства, убеждает в «пустоте» жизни, то есть отсутствии Бога. ${ }^{19}$

В духе барокко во «Второй книге Переселений» проявляется совмещение мистического и натуралистического начал: с одной стороны, Павел Исакович поддерживает постоянную духовную связь с умершей женой-возлюбленной, а с другой стороны, он находит себе в России исключительно здоровую и сильную бабу, способную своим дыханием, словно мехами, раздуть огонь в печи.

Антиномиям барокко в известной мере близок «амбивалентный» способ изображения действительности ${ }^{20}$, проявляющийся и у Црнянского. Так, «Вторая книга переселений» начинается сказочным зачином, создающим образ идеальной страны: «Было однажды одно королевство в центре Европы, которое называлось: Венгрия. В этом королевстве текли реки, богатые рыбой, а вдоль тех рек простирались бескрайние зеленые равнины». Однако уже два следующих предложения совершенно меняют восприятие этого мира: «Летом эти равнины превращались в жаркую пустыню, а зимой в ледяное море, покрытое снегом. Люди прислушивались, во мраке, к завыванию волков». Точно так же в конце «Второй книги Переселений» сообщается, что все начинания Павле Исаковича потерпели полный крах и что он полностью разочаровался в жизни. Однако тут же, с другой стороны, герой совершенно неожиданно заявляет, что он никогда не был так счастлив в жизни, как в России.

Можно также отметить, что Евдокия Божич, любовница Павла Исаковича, соблазнившая его вопреки его воле, практически одновременно уподобляется то дьяволу, то ангелу $(2,137)$.

Литература барокко, подчеркивая безжалостную власть времени, может, однако, признать способность человека противостоять его разрушительному воздействию. ${ }^{21}$ Подход Црнянского к Вуку Исаковичу в этом вопросе так же неоднозначен.

${ }^{19}$ В статье «Барочное пространство у Платонова» Н. Злыднева отмечает, что в

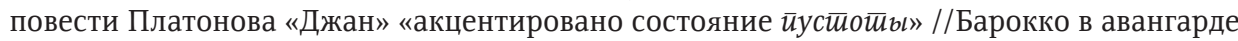
- авангард в барокко. М., 1993. С. 40.

${ }_{20}^{20}$ Барокко в авангарде - авангард в барокко. М., 1993. С. 44

21 В стихотворении барочного поэта из Дубровника Дживо (Ивана) Бунича (1591-1658) «Состарившаяся прекрасная Елена перед зеркалом» власть времени одновременно и утверждается (Елена «состарилась») и отрицается (нельзя погасить костер, уничтоживший Трою). У Црнянского в случае с королевой Вюртембергской, героиней «Переселений», все несколько проще. Состарившаяся красавица пытается вернуть молодость, одевшись как в юности, но «обнаженные плечи ее сияли, как высохшие на солнце кости» $(1,231)$. 
С одной стороны, писатель превращает молодого красавца в уродливого кривоного старика, с припухшими глазами, отвисшей грудью и огромным животом, старика, напоминающего бочонок. С другой стороны, этого «старика» страстно любит его молодая и прекрасная жена Дафина, а «героическая старость» Исаковича вызывает у солдат «глубокое уважение» $(1,353)$. Сам он в конце романа едет на коне «опять весь в серебре, умиротворенный и очищенный ... Последний раз в жизни он был красив» $(1,353)$.

Разрушительное воздействие времени - свидетельство преходящего характера земной жизни, что предполагает важное для барокко признание ее иллюзорности, уподобление сну, обращение к мотивам тени и раздвоении личности, что в полной мере присуще Црнянскому. Мотив тени, как и мотив сна, постоянно звучит в романе.

Призрачность, неестественность человеческого существования проявляется в литературе барокко и при помощи уподобления жизни театру. Чужой мир Вены напоминает Павлу Исаковичу «театр в Темишваре, где кривлялись на немецком» $(2,214)$. В дальнейшем в России Павлу самому придется самому участвовать в качестве комического героя в театральном представлении, организованном его врагами.

Естественно, что земная жизнь в барокко - это бессмысленность, тщетность, Vanitas, и это представление напоминает отношение буддизма к сансаре и полностью совпадает с представлениями Црнянского, постоянно подчеркивающего бессмысленность усилий всех героев.

Жизнью у Црнянского всегда управляет «комедиант случай», что совпадает как с концепцией барокко, так и с представлениями футуристов $^{22}$. Власти случая в полной мере подвержен Павле Исакович, герой литературы барокко. Как и его отчим Вук Исакович, он постоянно страдает, пребывая в состоянии дисгармонии, выступает как мученик идеи. Как и Вук Исакович, он в конце концов осознает тщетность борьбы и собственную обреченность, всевластие высшей враждебной силы. Как и Вук Исакович, он подвергается авторской иронии: обоих героев преследует эпитет «честнейший». ${ }^{23}$

В силу этого меланхолия, определяющая судьбу Павла Исаковича вполне объяснима: иррациональный, барочный взгляд на мир предполагал ощущение бренности бытия и, следовательно, презрения к радостям

\footnotetext{
22 « В России те, кого принято считать футуристами, именовались также экспрессионистами»// Энциклопедия экспрессионизма. С. 12.

${ }^{23}$ Как известно, именно страдающий герой , жертва дисгармонии, мученик долга или чести, в полной мере осознающий тщетность земной борьбы и ощущение собственной обреченности, игрушка неведомых и недоступных его пониманию сил, объект паторской иронии, - именно такой герой типичен для барокко.
} 
жизни. При этом меланхолия не всегда вызывалась личными обстоятельствами. Она могла также быть свидетельством кризиса общества. ${ }^{24}$

По классификации основных типов меланхоликов XVIII в. («сумазброды», «мисанфропы» и «щеголи») Павле Исакович должен был бы принадлежать к «мисанфропам», против которых выступал с гневной проповедью еще русский архиепископ Феофан Прокопович в «Слове о власти и чести царской» (1718 г.). Очевидно, что «сумазброды» и «щеголи», как представители менее опасных направлений, не заслуживали такого внимания.

Мизантроп же не верит в высшую справедливость. Жизнь окончательно теряет свою привлекательность, меланхолия еще глубже проникает в душу героя.

Однако изначально основной причиной меланхолии Павла Исаковича, по Црнянскому, выступает преждевременная смерть жены. Точно так же Ю.Кристева видит в меланхолии «темную подоснову любовной страсти», следствие потери возлюбленных. При этом, по ее словам, особую печаль у людей вызывает то, что они замечают в новом объекте любви тень давно потерянного прошлого 25.

То же самое и у Црнянского. Так, Павле Исакович, встречаясь с женой майора Божича Евдокией Божич, видит в ней черты своей жены, хотя между скромной Катинкой и распущенной Евдокией, кажется, нет ничего общего.

Сам Павле Исакович постоянно повторяет, что он вдовец и что его жизнь уже завершена. И чем более он это повторяет, тем более к нему тянутся женщины: и Евдокия, и ее дочь Фекла, и жены его братьев Варвара и Кумрия. Фактически на красавца Павла идет охота со стороны женщин. Мужчины-меланхолики, в отличие от женщин, пораженных той же болезнью, обретали в глазах окружающих особую притягательность.

Впрочем, по ходу действия Павле Исакович все более отдаляется от женщин и начинает приближаться к типу «сумазбродов»: эпитет «безумный» («безумный смех», «безумный взгляд») все чаще сопровождает его. Однако, как отмечалось, окружающие не видят в этом ничего ненормального или хотя бы странного.

Очевидно, что в подобном случае Павле Исакович может восприниматься и как барочный герой и как герой романтический, что вполне допустимо с учетом типологического схождения барокко и романтизма. Ведь сама меланхолия Исаковича легко может быть истолкована

\footnotetext{
${ }^{24}$ См.: Юханнисон К. История меланхолии. О страхе, скуке и чувствительности в прежние времена и теперь. М., 2011. 320 с.

${ }^{25}$ См.: Кристева Ю. Черное солнце. Депрессия и меланхолия. М., 2010. 292 с.
} 
в романтическом духе. Как известно, романтики любили меланхолию, возвышающую человека над толпой и пробуждающую творческие способности.

Меланхолия и разочарование в действительности порождают у Павле Исаковича мысли о магических силах, управляющих миром, что также соответствует представлениям барокко об иррациональном характере жизни. Так, в сходстве Евдокии Божич и Катинки герой видит «нечистые происки нечестивого» ${ }^{26}$. По мнению Исаковича здесь находит проявление «какая-то магия» $(2,135)$. В дальнейшем, в конце произведения, герой окончательно приходит к выводу, что «какая-то магия определяет жизнь человека, а не Бог или воля людская» $(2,475)$.

Известно, что магия может определять жизнь человека, когда тот встречается с неопределенностью и всевластием случая, а также тогда, когда возникает крайнее эмоциональное напряжение между надеждой и опасением. Магия как социальное явление в значительной мере представляет собой сублимацию страхов и надежд человечества. Проявление иррациональных сторон социальной психологии начинает снижаться в Западной Европе с конца ХУ11 в., то есть на пороге эпохи рационализма, однако к сербам рационализм приходит почти на столетие позже.

Передача духа эпохи - эпохи барокко - проявляется и в мечтаниях Павле Исаковича о встрече с императрицей Елизаветой Петровной. По мнению героя, разговор с императрицей может изменить к лучшему судьбу сербского «национа» в России, что вполне соответствует представлениям времени: тема божественности государя - одна из постоянных тем барокко.

При этом «божественность» государыни в дальнейшем осмеивается: Павле Исаковичу под видом императрицы представляют жену русского офицера, которая при встрече ведет себя весьма фривольно и тем самым выступает в роли двойника-пародии на Елизавету, так как о моральном облике русской императрицы Црнянский отзывается не слишком лестно. Однако и в этом осмеянии «божественности» императрицы содержится присущее барокко совмещение иллюзии и реальности: ведь и сама императрица ведет себя фривольно и, кроме того, некоторые сербские офицеры действительно встречаются с Елизаветой.

Модернистское миросозерцание Црнянского, опирающееся на традиции барокко и на буддизм, символическое видение жизни, не предполагало отказа от изображения исторической действительности. Писатель опирается на факты, документы, широко использует «Мемуары» Симеона Пишчевича, сербского офицера, переселившегося в середине ХУ111 века в Россию и дослужившегося до чина генерал-майора.

\footnotetext{
${ }^{26}$ У Црнянского слово «нечестивый» написано с заглавной буквы.
} 
Однако концепция истории у писателя подчинена его собственным воззрениям, его барочному взгляду на мир. В духе барочных воззрений дана у Црнянского и сама концепция переселения. Конечно, писатель раскрывает конкретно-исторические причины переселения: нежелание сербских солдат переходить на положение крепостных, агитация представителей Российской империи, надежда сербских офицеров сделать карьеру - и об этом сказано довольно много. Однако главное в произведении - это устремленность к высшим ценностям и последующее разочарование Павле Исаковича.

При этом метафизические идеи героя определяют и концепцию исторических событий. Вместе с Павле в романе разочарование переживает и весь сербский народ, в то время как история дает другую картину. В соответствии со свидетельством Симеона Пишчевича в русской армии в то время было 25 сербских генералов, 17 полковников, 8 подполковников и 37 майоров, в то время как на территории Австрии сербам в основном доставались лишь самые нижние офицерские чины прапорщика, подпоручика и поручика. Капитанский чин в Австрии считался высшим достижением для сербов, а майоров, подполковников и полковников среди них было не более 20 человек за всю первую половину ХУ111 века. И это с учетом того, что в Россию переселилось около десяти тысяч человек, а число сербов-граничар, прикрывающих приграничные рубежи Австрии, достигало 50 тысяч.

Даже простые солдаты, переселившиеся в Россию, со временем оказались в лучшей ситуации, чем на территории Австрии. С. Пишчевич отмечает, что вначале жизнь была трудной, приходилось обживаться, не хватало продуктов, однако со временем все наладилось. О радушном приеме в России говорят и современные сербские историки: «...Необходимо сказать, что прием, который ждал сербов в России, и особенно огромные средства, которые им были выделены для строительства жилья, обусловили быстрое решение проблем и экономический подъем» ${ }^{27}$.

Конечно, было бы наивным предполагать, что Црнянскому не были известны исторические факты или что сербский писатель хотел очернить Россию. В тексте «Я исполнил свое предназначение» писатель отмечал, что переселение сербов было обусловлено реальными историческими причинами и в нем не было ничего «божественного». Стремление сербов к единению «с братским единоверным народом» явно отступало на второй план $(3,376)$.

И если народ испытывал какие-то трудности, то обусловлены они были злоупотреблениями со стороны высшего сербского офицерства. И не случайно Йован Хорват, первым получивший чин генерал-майора и

\footnotetext{
${ }^{27}$ Историја српского народа.Београд, 2000. IV-1. Срби у XVIII веку. С. 247.
} 
претендовавший на всевластие над сербами, в 1763 г. за злоупотребления лишился пожалованных чина и имения и был сослан в Вологду.

Однако восприятие России дано с точки зрения Павле Исаковича, человека, устремленного к идеалу и не признающего реальной жизни. Барочный, меланхолический взгляд окрашивает весь мир в мрачные цвета. И совершенно естественно, что «Вторая книга Переселений» завершается сообщением о растворении сербского «национа» в России. И тут же парадоксально, в духе барокко, звучат уже упоминавшиеся финальные слова: «Есть переселения. Смерти нет!». Не случайно и название последней главы романа: «Переселения продолжаются вечно». Таким образом, одна заключительная фраза романа создает высокое напряжение между полюсами смерти и жизни.

Вечное движение, динамизм жизни, утверждаемые как буддизмом, так и барокко, по мнению Е. Г. Яковлева, обусловлены перспективным выходом в незавершенность, что соответствует концепции «non-finito» в западноевропейском модернистском искусстве ${ }^{28}$.

«Выход в незавершенность», концепция «non-finito» у Црнянского наиболее ясно проявляется в «Записках о Чарноевиче», где отсутствует строгий сюжет, а воображение художника раскрывает иррациональную, мистическую суть бытия.

То же, очевидно, наблюдается и в «Переселениях». В самом конце романа сообщается, что «зерно прежней молодости», сохранившееся в душе Вука Исаковича, может вновь прорасти и вознести новые существа над временем и над самим небом. Движение остается незавершенным и предполагает выход за пределы конкретной, материально-осязаемой действительности, что естественно сочетается с основными положениями буддийской антологии, «которая является антологией бессубстратного процесса, то есть бытие не есть некая постоянная вечная субстанция, или сущность, а процесс, который опять-таки не опирается ни на какую вечную основу» ${ }^{29}$.

Другим источником, порождающим принцип динамизма, по мнению А.Н. Штейна, являются внутренние противоречия и антагонизм барокко, что вновь свидетельствует об антиномичности как важнейшем принципе этого направления и творческого метода.

Однако сама антиномия нуждается в антиномии. Антиномический характер видения мира в барокко сочетается с положением о тесной взаимосвязи всего сущего, соединении бесконечно далекого, «том-

\footnotetext{
${ }^{28}$ Яковлев Е. Г. Искусство и мировые религии. С. 154, 156.

${ }^{29}$ Торчинов Е. А. Философия буддизма махаяны. СПб., 2000. С. 49.
} 
лении» по дополняющему до целостности. ${ }^{30}$ «Суматраизм» Црнянского, таким образом, вполне укладывается в барочную концепцию действительности.

Мысль о единстве мира проявляется в барокко и через принцип отражения. В «ПереселенияХ» отношения Вука и его жены Дафины находят зеркальное отражение в отношениях Дафина - брат Вука Аранжел Исаакович. Дафина любит мужа, в то время как он равнодушен к ней, и та же Дафина равнодушна к влюбленному в нее Аранжелу. «Различные вещи, увиденные глазами различных людей, представлены в «Переселениях» таким образом, что читатель невольно видит одно в другом»,писал Н. Петкович ${ }^{31}$.

Очевидно, что параллели между творчеством Црнянского и литературой барокко не случайны. Известно, что экспрессионисты в 20-е годы уделяли серьезное внимание изучению этого направления, к традициям барокко обращались романтики. «Схождения между барокко и романтизмом объясняются тем, что они, по определению Д.С.Лихачева, относятся к так называемым вторичным стилям. И барокко и романтизм развивали теорию самостоятельной жизни искусства» ${ }^{32}$. Но и « в экспрессионизме изображаемое и изображенное сильно расходятся... Изображенное в его конкретности - всего лишь призыв понять то, что изображено» ${ }^{33}$.

Таким образом, барокко «как стиль (мышления, жизни, искусства) предстает не только и не столько в виде хронологического и локализованного эпизода истории, сколько в виде вневременной категории, циклическое возникновение которой обнаруживается в культурах других эпох», - пишет Л. Софронова, что совпадает с мнением других исследо-

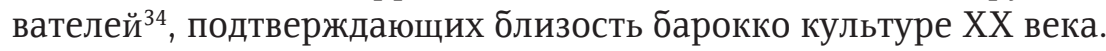

Уже в XVII веке представители эпохи барокко свой стиль называли «модернизмом» ${ }^{35}$. По словам Ж. Бенчич, « и барочных писателей, и авангардистов характеризует повышенное сознание собственного «модернитета» и в связи с этим одинаковое отношение к литературной традиции. И барокко, и авангард нарушают узаконенные традицией поэти-

${ }^{30}$ И. Н. Голенищев-Кутузов отмечал: «Наиболее последовательно из всех теоретиков барокко Тезауро разработал учение о сходимости несходимого, о Метафоре, связывающей силой творческого остроумия предметы или идеи, кажущиеся бесконечно далекими». «Романские литературы» М.,1975. С. 331.

${ }^{31}$ Петковић Н. Два српска романа Београд, 1988. С. 247.

32 Барокко в славянских культурах. М., 1982. С. 11.

33 Энциклопедия экспрессионизма. С. 8.

${ }^{34}$ Рогов А. И. Проблемы славянского барокко // Славянское барокко. М., 1979. С. 12; Довга Л. М. Эстетические основы культуры барокко. Киев, 1991. С. 1.

${ }^{35}$ Голенищев-Кутузов Н. И. Романские литературы. С. 213. 
ческие нормы...» ${ }^{36}$ Близость барокко и авангарда подтверждают и другие исследователи ${ }^{37}$.

При этом следует отметить, что барочные традиции в основном проявляются в «Переселениях» Црнянского, когда авангардизм в Сербии был близок к закату ${ }^{38}$.

Сам М. Црнянский в своих эссе и путевых записках почти не упоминает литературу барокко, лишь иногда подчеркивая красоту барочной архитектуры $^{39}$. Исключением из правила могут стать слова о «барочной патетике» Негоша, о «волшебном очаровании» его стихов, о стремлении самого Црнянского к «чудесному в поэзии» $(10,16)$. Однако довольно часто писатель в своих эссе обращается к барочным мотивам тени и сна, их важности в жизни человека. Подобием сновидения представлялось ему и творчество Ибсена.

Несмотря на сдержанность высказываний Црнянского относительно традиций барокко в его творчестве, очевидно, что ему, как экспрессионисту, не чужды представления человека XVII века. Многочисленные совпадения концепции барокко с опытом буддизма также не случайны. Е.Г. Яковлев, выявляя в основном параллели между буддизмом и модернистским искусством, также ссылается на присущие барокко и буддизму тяготение к метафоре. ${ }^{40}$

Определенная близость буддизму проявляется также при рассмотрении психоанализа и родственных явлений. Е. В. Завадская отмечала, что « в теории 3. Фрейда и К. Юнга есть ряд идей, аналогичных дзэнской этике и психологии» ${ }^{41}$. Основоположник неофрейдизма Э. Фромм предлагал «четыре благородные истины Будды» в качестве рецепта современному человечеству, противопоставляя ценность бытия иллюзорности обладания. То же самое утверждал и сотрудничавший с ним Д. Т. Судзуки. По словам японского ученого, «желание обладать чем-либо

${ }^{36}$ Барокко в авангарде - авангард в барокко. С. 7.

${ }^{37}$ См. Барокко в авангарде - авангард в барокко, а также Е. Бирюков. Уроки барокко и авангарда. Тамбов. 1998.

38 Об усилении тяги к барокко, которым отмечен авангард « на излете», пишет Н.Злыднева//Барокко в авангарде. С. 40.

${ }^{39}$ Известно, что Црнянский проводил часы в созерцании купола Микеланджело, а, по словам Н. Злыдневой, «позднее творчество Микеланджело (перестройка собора св. Петра в Риме)» - «хрестоматийный пример» барокко «на ранней стадии развития стиля»// Барокко в авангарде - авангард в барокко. С.41. Ссылаясь на общепринятое мнение, «отцом барокко» называет Микеланджело В. Г. Власов. // Архитектура. М., 2003. C.47. О прославлении «ухода в небытие» в стихах Микеланджело пишет С. Д. Артамонов. История зарубежной литературы XVII-XVIII веков. С. 18.

40 Яковлев Е. Г. Искусство и мировые религии. С. 154, 167.

${ }^{41}$ Завадская Е. В. Восток на Западе. М., 1970. С. 43. 
считается в буддизме самой дурной страстью» ${ }^{2}$. Причем принцип «обладания» и у Судзуки и у Фромма распространялся и на знание, хотя немецкий психолог все же противопоставлял истинное знание « обладанию» знанием, а для Судзуки «всякое знание» лишь «приобретение и накопление», что неприемлемо для дзэна.

Другое свидетельство общности буддизма и фрейдизма, а именно нерасчлененность субъекта и объекта, проявляется при анализе структуры личности, проведенным А. М. Пятигорским и Б. А. Успенским ${ }^{43}$.

Таким образом, в творчестве Црнянского экспрессионизм закономерно сочетается с романтизмом и барокко, а барочные представления о мире совпадают с буддийскми воззрениями. Не случаен интерес сербского писателя и к Фрейду, а также к Кьеркегору ${ }^{44}$ и Ницше, причисленным Э.Фроммом к предтечам психоанализа.

Безусловно, Црнянскому, с одной стороны, присуще неклассическое, динамическое восприятие действительности. С другой стороны, очевиден интерес писателя к искусству классическому - искусству античности. При этом Микеланджело, Ибсен, Стриндберг, Фрейд помогают художнику-авангардисту перекинуть мост в мир древних греков и римлян. Устремленность к неизменной вечности сочетается у Црнянского с пристальным вниманием к бесконечности мгновений, бесконечности незавершенной, вечно изменяющейся. Авангардистские устремления сливаются с традицией ${ }^{45}$.

\section{Литература}

Абаев Н. В. Чань-буддизм и культурно-психологические традиции в средневековом Китае. М., 1983.

Артамонов С. Д. История зарубежной литературы XVII-XVIII веков. М., 1988. Барокко в авангарде - авангард в барокко. М.,1993.

Барокко в славянских культурах. М., 1982.

Голенищев-Кутузов И. Н. Романские литературы. М., 1975.

Буддизм. Четыре благородные истины. Москва-Харьков, 1999.

Завадская Е. Г. Восток на Западе. М., 1970.

Ильина Г. Я. Развитие югославского романа в 20-30-е годы ХХ в. М., 1985.

Костелянец Б. О. Драма и действие. М., 2007.

42 Четыре благородные истины. С. 740.

43 Пятигорский А. М., Успенский Б. А. Персонологическая классификация как семиотическая проблема// Семиотика. Тарту, 1967. Выпуск 3.

44 «Философия ...Кьеркегора...имеет весьма существенные черты сходства с учением дзэн»//Завадская Е. В. Восток на Западе. С. 42.

45 Единство авангарда и традиции было рассмотрено в рамках международной анкеты, проведенной серббскй газетой «Књижевна реч» в 1980-1982 гг.// Теšić G. Avangarda i tradicija. Beograd, 2002. 284. 
Кристева Ю. Черное солнце. Депрессия и меланхолия. М., 2010.

Ортега-и-Гассет. Эстетика. Философия культуры. М., 1991.

Пятигорский А. М., Успенский Б. А. Персоналогическая классификация как семиотическая проблема// Семиотика. Тарту, 1967. Выпуск 3.

Розенберг О. О. Труды по буддизму. М., 1991.

Славянское барокко. М., 1979.

Топоров В. Л. Поэзия эпохи перемен//Сумерки человечества. Лирика

немецкого экспрессионизма. М., 1990. С. 5-16.

Шабуров Н. В. и др. Религии мира. М., 1997.

Штейн А. Л. Литература испанского барокко. М., 1983.

Энциклопедия экспрессионизма. М, 2003.

Юханнисон К. История меланхолии. О страхе, скуке и Чувствительности в прежние времена и теперь. М., 2011.

Яковлев Е. Г. Искусство и мировые религии. М., 1985.

Историја српског народа. Београд, 2000. T. IV-1.

Итака. Ревија за књижевност, уметност и мишљење. Нулти број. Београд, 1995.

Кораћ С. Српски роман између два рата. Београд, 1982.

Ломпар М. Црњански и Мефистофел. Београд, 2000.

Петковић Н. Два српска романа. Београд, 1988.

Радуловић М. Модернизам и српска идеалистичка философија. Београд, 1989.

Сербиа и коментари за 1993/1995. Београд, 1996.

Српски симболизам. Београд, 1985.

Црњански М. Сабрана дела. Београд, 1966.

Vučković R. Poetika hrvatskog i srpskog ekspresionizma. Sarajevo, 1979.

Kuper Dž. Ilustrovana enciklopedija tradicionalnih simbola. Beograd, 1986.

Tešić G. Avangarda i tradicija. Beograd, 2002.

Sergey N. Meshcheryakov

\section{MILOŠ CRNJANSKI: EXPERIENCE OF CENTURIES AND CIVILIZATIONS}

\section{Summary}

The article of the Serbian writer M. Crnjanski shows interaction of three styles in literature - expressionism, romanticism, baroque - with the traditions of Buddhism. The work of Crnjanski has become an embodiment of united achievements of the European and Oriental civilization.

Keywords: Crnjanski, expressionism, romanticism, baroque, Buddhism 